\title{
Risk factors for unstable blood glucose level: integrative review of the risk factors related to the nursing diagnosis
}

\author{
Andressa Magalhães Teixeira ${ }^{1}$ \\ Rosangela Tsukamoto ${ }^{2}$ \\ Camila Takáo Lopes $^{3}$ \\ Rita de Cassia Gengo e Silva ${ }^{4}$
}

Objective: to identify evidence in the literature on the possible risk factors for the risk of unstable blood glucose diagnosis in individuals with type 2 diabetes mellitus, and to compare them with the risk factors described by NANDA International. Method: an integrative literature review guided by the question: what are the risk factors for unstable blood glucose level in people with type 2 diabetes mellitus? Primary studies were included whose outcomes were variations in glycemic levels, published in English, Portuguese or Spanish, in PubMed or CINAHL between 2010 and 2015. Results: altered levels of glycated hemoglobin, body mass index $>31$ $\mathrm{kg} / \mathrm{m}^{2}$, previous history of hypoglycemia, cognitive deficit/dementia, autonomic cardiovascular neuropathy, comorbidities and weight loss corresponded to risk factors described in NANDA International. Other risk factors identified were: advanced age, black skin color, longer length of diabetes diagnosis, daytime sleepiness, macroalbuminuria, genetic polymorphisms, insulin therapy, use of oral antidiabetics, and use of metoclopramide, inadequate physical activity and low fasting glycemia. Conclusions: risk factors for the diagnosis, risk for unstable blood glucose level, for persons with type 2 diabetes mellitus were identified, and $42 \%$ of them corresponded to those of NANDA International. These findings may contribute to the practice of clinical nurses in preventing the deleterious effects of glycemic variation.

Descriptors: Diabetes Mellitus, Type 2; Nursing Diagnosis; Risk Factors; Hypoglycemia; Hyperglycemia.

\section{How to cite this article}

Teixeira AM, Tsukamoto R, Lopes CT, Silva RCG. Risk factors for unstable blood glucose level: integrative review of the risk factors related to the nursing diagnosis. Rev. Latino-Am. Enfermagem. 2017;25:e2893. [Access ${ }^{\prime}+$ f ] Available in: DOI: http://dx.doi.org/10.1590/1518-8345.1688.2893. 


\section{Introduction}

Risk for unstable blood glucose level (00179) is a NANDA International, Inc. (NANDA-I) nursing diagnosis (ND), defined as "Vulnerable to variation in blood glucose/sugar levels from the normal range, which may compromise health"(1).

In the latest NANDA-I diagnostic classification edition, 16 risk factors for this ND are described: alteration in mental status, average daily physical activity is less than recommended for gender and age; compromised physical health status; delay in cognitive development; does not accept diagnosis; excessive stress; excessive weight gain; excessive weight loss, inadequate blood glucose monitoring; ineffective medication management; insufficient diabetes management; insufficient dietary intake; insufficient knowledge of disease management; nonadherence to diabetes management plan; pregnancy; and rapid growth period $^{(2-3)}$, which are used to identify this diagnosis in patients of different clinical profiles or health-disease conditions.

Among these conditions, a special interest in type 2 diabetes mellitus (DM2) is demonstrated in this study. In a study that investigated 30 people during home nursing consultations, $60 \%$ had unstable glycemic risk(4). In another study with diabetic patients in outpatient care, $28.6 \%$ of the participants had this $\mathrm{ND}^{(5)}$.

Studies demonstrate that variation in glycemic levels may: increase the rate of complications and mortality in hospitalized patients with acute coronary syndrome(6), compromise renal function and structure $^{(7)}$, and lead to endothelial dysfunction ${ }^{(8)}$. These consequences can have negative impact on productivity, quality of life and survival, and involve high costs related to treatment ${ }^{(9)}$. Thus, the recognition of risk factors for unstable glycemia and the institution of preventive measures can contribute to positive results for which nurses have responsibility.

The recognition of the risk factors of this ND may occur due to the nurse's knowledge, his previous experiences, and by means of consultation of available scientific literature, among others. In clinical practice, NANDA-I diagnosis classification is an important, easily accessible resource that guides nurses in recognizing risk factors, and in the clinical decisionmaking process.

The movement of researchers to improve the NANDA-I diagnosis classification, including new diagnostic elements, is current in the literature. In a literature review, 79 defining characteristics of the diagnosis of decreased cardiac output (00029) were identified, of which 28 were approved by NANDA-I and the others were identified as possible indicators of this diagnosis ${ }^{(10)}$. In another study, researchers found that the distances in the six-minute walk test were predictive of ineffective peripheral tissue perfusion (00204) and suggested that this could be a defining characteristic of that diagnosis ${ }^{(11)}$.

Risk for unstable blood glucose level is supported by three references published between 2003 and $2005^{(1)}$. Therefore, reviewing the ND and supporting its elements, such as risk factors, in current literature is of fundamental importance.

In this context, the objectives of this study were to identify evidence in the literature regarding possible risk factors for the diagnosis of risk for unstable blood glucose level for individuals with DM2, and to compare them with the risk factors described by NANDA-I.

\section{Method}

This literature integrative review was conducted according to the following steps: identification of the research question; definition of the criteria for inclusion and exclusion of studies; categorization and evaluation of studies; extraction and interpretation of results; and synthesis of knowledge (12). The question that led to the survey data was: What are the risk factors for unstable glycemia in people with type 2 diabetes mellitus?

The PICO [P(problem or patient) I (intervention) C (comparison) O (outcomes)] acronym $^{(13)}$ was used to develop strategies for searching the PubMed portal (National Library of Medicine and the National Institutes of Health) and CINAHL database (Cumulative Index to nursing Allied Health Literature), as described in Figure 1. These two databases were chosen because they include the main journals in the health and nursing areas that involve the subject of interest for the present study.

The search was performed from October to November of 2015. Initially, the terms "risk factor" and "risk factors" were used in the search strategy, but results obtained were nonspecific. The use of these terms provided articles in which unstable glycemia was a risk factor for other diseases. Therefore, these terms were suppressed, which made the search results more specific and better answered the research question and, therefore, its replacement was not necessary.

In order to be included in this review, the studies needed to meet the following inclusion criteria: to investigate variation in blood sugar levels that may compromise health as an outcome, defined as that which increases or decreases serum glucose; be a 
primary study with a longitudinal design (retrospective or prospective cohort, or case-control), cross-sectional study (in which the causal relationship between the antecedent variable and the outcome was clear), or an experimental study; have an abstract and full text available in the databases mentioned above; published between 2010 and 2015, in Portuguese, English or Spanish; and have adequate methodological quality.

An adequate methodological quality was assessed according to a consistency with $50 \%$ or more of the items in the STROBE (Strengthening the Reporting of Observational Studies in Epidemiology) Statement as Barbosa, Vasconcelos, Correia, \& Ferreira ${ }^{(14)}$ and Silva, Lyra, \& Lima ${ }^{(15)}$ used in their studies.

This tool was used because it guides the organization of scientific writing of observational studies, indicating essential elements that must be contained in the manuscripts. Articles with an agreement of $50 \%$ or more of the STROBE items were considered to have adequate methodological quality. This evaluation was performed by two evaluators, independently, and inconsistencies were resolved by consensus.
The level of evidence from included studies was assessed according to the Oxford Centre for Evidencebased Medicine classification for etiology: 2b: cohort study, 3b: case-control study; 4: studies without clear definition of comparison groups that do not measure exposure and outcome, without patient follow-up (used to classify cross-sectional studies)(16).

The studies excluded were those testing the efficacy or effectiveness of medications, measures for glycemic control, and studies including people with other types of diabetes with results that did not evaluate those with T2DM separately. Figure 2 shows a summary of the study selection process.

After this classification, possible correspondences with the risk factors currently described by NANDA-I were evaluated by consensus among the researchers.

For the extraction of the data of interest, an instrument developed by the researchers was used, containing: title; objective; design; sample; results; and risk factors identified in the article. Data were extracted by two evaluators independently. Inconsistencies were resolved by consensus between the two.

\begin{tabular}{|c|c|c|}
\hline Acronym & PubMed & CINAHL \\
\hline P (Problem or Patient) & diabetes mellitus (MeSH terms) & "Diabetes Mellitus, Type2” (CINAHL titles) \\
\hline $\begin{array}{l}\text { I (Intervention or } \\
\text { phenomenon of interest) }\end{array}$ & $\begin{array}{l}\text { "risk factor" (MeSH terms) or "risk factors" (MeSH terms) } \\
\text { or "risk factor" (all fields) "risk factors" (all fields) }\end{array}$ & $\begin{array}{l}\text { risk factor" (CINAHL titles) or "risk factors" (CINAHL titles) } \\
\text { or "risk factor" (all fields) "risk factors" (all fields) }\end{array}$ \\
\hline C (Comparison) & \multicolumn{2}{|l|}{ No terms were used for comparison } \\
\hline O (Outcomes) & $\begin{array}{l}\text { hypoglycemia (MeSH terms) or hyperglycemia (MeSH } \\
\text { terms) or hypoglycemia (all fields) or hyperglycemia } \\
\text { (all fields) or 'glycemic variability' (all fields) or 'glucose } \\
\text { imbalance'(all fields) }\end{array}$ & $\begin{array}{l}\text { "Hypoglycemia" (CINAHL titles) or "hypoglycemia" or } \\
\text { "Hyperglycemia" (CINAHL titles) or "hyperglycemia" or } \\
\text { "glycemic variability" (all fields) or "glucose imbalance" } \\
\text { (all fields) }\end{array}$ \\
\hline
\end{tabular}

Figure 1 - Search strategy used. São Paulo, SP, Brazil, 2015
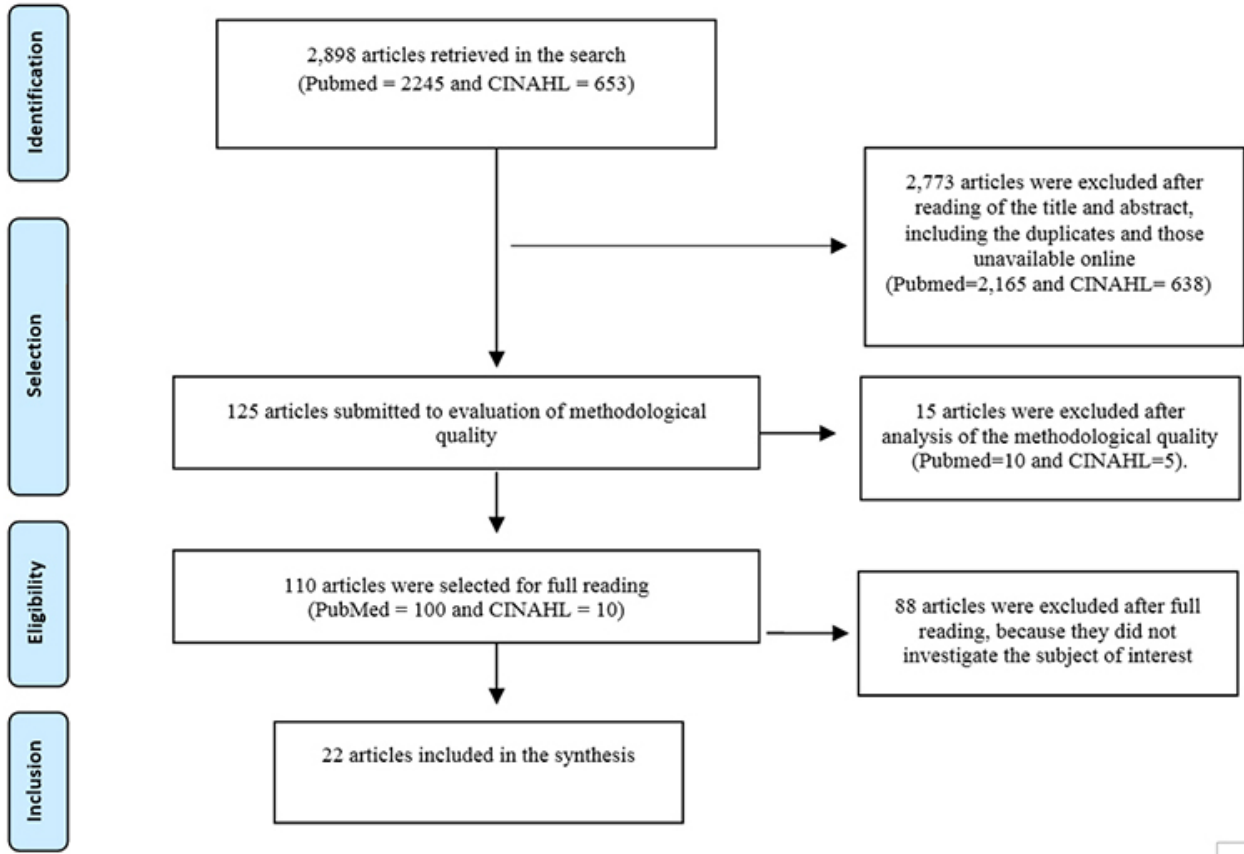

22 articles included in the synthesis

Figure 2 - Flow chart of the study selection process. 
Risk factors were classified as factors associated with a greater likelihood of increasing blood glucose levels, and factors associated with a greater likelihood of lowering blood glucose levels.

\section{Results}

Twenty-two primary studies met the eligibility criteria. All were published in English or Spanish. The countries of origin of the articles were the United States $(n=6)$, Germany $(n=4)$, Japan $(n=2)$, Korea $(n=2)$, United Kingdom $(n=1)$, Turkey $(n=1)$, Czech Republic $(n=1)$, Greece $(n=1)$, Mexico $(n=1)$,
Italy $(n=1)$, China $(n=1)$, and England $(n=1)$. The characteristics of these studies are demonstrated in Figure 3.

Figure 4 describes the risk factors for unstable blood glucose levels identified in this review, and possible correspondences with six risk factors proposed by NANDA-I: insufficient diabetes management; excessive weight gain, compromised physical health status; alteration in mental status; delay in cognitive development; and excessive weight loss.

Figure 5 describes additional risk factors for which no correspondences were established with the NANDA-I classification.

\begin{tabular}{|c|c|c|c|c|c|}
\hline $\begin{array}{l}\text { Title of the article and } \\
\text { country of publication }\end{array}$ & Objective & Design and casuistry & $\begin{array}{l}\text { Risk Factor } \\
\text { identified }\end{array}$ & $\begin{array}{c}\text { Measures of effect } \\
\text { and } \mathrm{Cl} 95 \% \pi \text { (when } \\
\text { available) }\end{array}$ & $\begin{array}{l}\text { Level of } \\
\text { evidence }\end{array}$ \\
\hline $\begin{array}{l}\text { Relationship between } \\
\mathrm{HbA} 1 \mathrm{C}, \text { hypoglycemia, } \\
\text { and hyperglycemia in } \\
\text { Japanese with type } 2 \\
\text { diabetes - results from } \\
\text { continuous glucose } \\
\text { monitoring data }{ }^{(17)} \\
\text { Japan }\end{array}$ & $\begin{array}{l}\text { To assess the frequency } \\
\text { and duration of } \\
\text { hypoglycemia, and } \\
\text { duration of hyperglycemia, } \\
\text { according to HbA1c* } \\
\text { in Japanese patients } \\
\text { with } \mathrm{DM} 2^{+} \text {treated with } \\
\text { hypoglycemic agents }\end{array}$ & $\begin{array}{l}\text { Prospective cohort, non- } \\
\text { probabilistic sample of } 40 \\
\text { hospitalized DM2 patients } \\
\text { treated with more than one } \\
\text { hypoglycemic agent }\end{array}$ & High level of HbA1c*. & $\begin{array}{l}\text { Mean total hyperglycemia } \\
\text { duration: } 50 \text { min }(P \\
25-75=0-550 \mathrm{~min}) \text { in } \\
\text { the low } \mathrm{HbA} 1 \mathrm{c}^{*} \text { group, } \\
302.5 \mathrm{~min}(\mathrm{P} 25-75 \\
=220-500 \mathrm{~min}) \text { in the } \\
\text { intermediate HbA1c } \\
\text { group, and } 660 \text { min (P } \\
25-75=185-830 \mathrm{~min}) \text { in } \\
\text { the high } \mathrm{HbA} 1 \mathrm{c}^{*} \text { group }(\mathrm{P} \\
=0.022) .\end{array}$ & $2 b$ \\
\hline $\begin{array}{l}\text { Impact of postprandial } \\
\text { and fasting glucose } \\
\text { concentrations on } \mathrm{HbA} 1 \mathrm{c} \\
\text { in patients with type } 2 \\
\text { diabetes }{ }^{(18)} \\
\text { Germany }\end{array}$ & $\begin{array}{l}\text { To assess the relative } \\
\text { contribution of } \\
\text { postprandial and fasting } \\
\text { glucose concentrations to } \\
\text { hyperglycemia in general, } \\
\text { in patients with type } 2 \\
\mathrm{DM}^{+} \text {who were previously } \\
\text { treated with diet, exercise, } \\
\text { and metformin }\end{array}$ & $\begin{array}{l}\text { Prospective Cohort } \\
973 \text { patients with type } 2 \\
\mathrm{DM}^{\dagger}, \text { recruited by European } \\
\text { Exenatide, aged } 18-85 \text { years } \\
\text { with Body Mass Index } \\
>25 \text { e }<40 \text { with stable } \\
\text { metformin dose for } 3 \\
\text { months, }\end{array}$ & $\begin{array}{l}\text { high } \mathrm{HbA} 1 \mathrm{c}^{*} \text { with high } \\
\text { fasting hyperglycemia }\end{array}$ & $\begin{array}{l}\text { AUC ROC§ for HbA1c* } \\
\geq 6.5=17.5 \pm 10.8 \mathrm{mmol} \\
\mathrm{h} / \mathrm{l} \text { versus AUC ROC§} \\
\text { for } \mathrm{HbA} 1 \mathrm{c}^{*}<6.5=13.3 \\
\pm 10.7 \mathrm{mmol} \mathrm{h} / \mathrm{L}, \mathrm{r}^{2}= \\
37.4 \%\end{array}$ & $2 b$ \\
\hline $\begin{array}{l}\text { Mild hypoglycemic } \\
\text { attacks induced by } \\
\text { sulphonylureas related to } \\
\text { CYP2C9, CYP2C19 and } \\
\text { CYP2C8 polymorphisms } \\
\text { in routine clinical } \\
\text { setting }{ }^{(19)} \\
\text { Turkey }\end{array}$ & $\begin{array}{l}\text { To study the impact of } \\
\text { CYP2C9, CYP2C19 and } \\
\text { CYP2C8 polymorphisms } \\
\text { on the risk of mild } \\
\text { hypoglycemia in patients } \\
\text { treated with sulfonylureas }\end{array}$ & $\begin{array}{l}\text { Prospective cohort, } \\
\text { non-probabilistic sample } \\
\text { of } 109 \text { patients with type } \\
2 \mathrm{DM}^{\dagger}, \text { aged } 33-80 \text { years, } \\
\text { treated with oral antidiabetic } \\
\text { medicine }\end{array}$ & $\begin{array}{l}\text { Products CYP2C9 } \\
\text { variant allele } \\
\text { may be modestly } \\
\text { associated with } \\
\text { mild hypoglycemia } \\
\text { during sulfonylurea } \\
\text { treatment }\end{array}$ & $\begin{array}{l}\text { Allele*1/*2 } \text { or }^{*} 1 /^{*}: 80 \% \\
\text { in the hypoglycemic } \\
\text { group versus } 32 \% \text { in } \\
\text { the non-hypoglycemic } \\
\text { group; Allele* } 2 /^{*} 2,{ }^{*} 2 \\
/^{*} 3 \text { or }^{*} 3 /^{*} 3: 20 \% \text { in } \\
\text { the hypoglycemic group } \\
\text { versus } 7 \% \text { in the non- } \\
\text { hypoglycemic group, } p= \\
0.035, \text { but there was no } \\
\text { statistical significance in } \\
\text { the logistic regression. }\end{array}$ & $2 b$ \\
\hline $\begin{array}{l}\text { Poor Cognitive Function } \\
\text { and Risk of Severe } \\
\text { Hypoglycemia in Type } \\
2 \text { Diabetes: post hoc } \\
\text { epidemiologic analysis of } \\
\text { the ACCORD trial(20) } \\
\text { United States }\end{array}$ & & $\begin{array}{l}\text { Prospective cohort, } \\
\text { a probability sample of } \\
2956 \text { participants aged } 40 \\
\text { to } 79 \text { years with type } 2 \mathrm{DM}^{\dagger} \\
\text { and } \mathrm{HbA} 1 \mathrm{C}^{*}>7.5 \% \text {, and } \\
\text { those who had a high risk of } \\
\text { cardiovascular disease }\end{array}$ & $\begin{array}{l}\text { Deficit in the cognitive } \\
\text { state }\end{array}$ & $\begin{array}{l}\mathrm{HR}^{\|}=1.13, \mathrm{Cl} 95 \% \pi: \\
1.08-1.18\end{array}$ & $2 b$ \\
\hline $\begin{array}{l}\text { Presence of } \\
\text { Macroalbuminuria } \\
\text { Predicts Severe } \\
\text { Hypoglycemia in Patients } \\
\text { With Type } 2 \text { Diabetes } \\
\text { Korea }\end{array}$ & $\begin{array}{l}\text { To investigate the } \\
\text { incidence and } \\
\text { predisposing factors } \\
\text { related to the development } \\
\text { of severe hypoglycemia } \\
\text { among patients with } \\
\text { type } 2 \mathrm{DM}^{\dagger} \text {, especially in } \\
\text { people with normal kidney } \\
\text { function }\end{array}$ & $\begin{array}{l}\text { Prospective cohort, } \\
\text { probability sample of } 1,217 \\
\text { patients with type } 2 \mathrm{DM}^{\dagger} \\
\text { aged } 25-75 \text { years }\end{array}$ & $\begin{array}{l}\text { Longer duration } \\
\text { of diabetes and } \\
\text { presence of } \\
\text { macroalbuminuria }\end{array}$ & $\begin{array}{l}\text { Duration of diabetes }\left(\mathrm{HR}^{\|}\right. \\
=1.04,95 \% \mathrm{Cl}: 1.01 \\
-1.07) \\
\text { Macroalbuminuria }(\mathrm{HR} \geq \\
2.52,95 \% \mathrm{Cl}: 1.31-4.84)\end{array}$ & $2 b$ \\
\hline
\end{tabular}




\begin{tabular}{|c|c|c|c|c|c|}
\hline $\begin{array}{l}\text { Title of the article and } \\
\text { country of publication }\end{array}$ & Objective & Design and casuistry & $\begin{array}{l}\text { Risk Factor } \\
\text { identified }\end{array}$ & $\begin{array}{c}\text { Measures of effect } \\
\text { and } \mathrm{CI} 95 \%{ }^{\pi} \text { (when } \\
\text { available) }\end{array}$ & $\begin{array}{l}\text { Level of } \\
\text { evidence }\end{array}$ \\
\hline $\begin{array}{l}\text { Severe hypoglycemia } \\
\text { requiring the assistance } \\
\text { of emergency medical } \\
\text { services - frequency, } \\
\text { causes and symptoms } \\
\text { Czech republic }\end{array}$ & $\begin{array}{l}\text { To assess the incidence of } \\
\text { severe hypoglycemia and } \\
\text { to describe the distribution } \\
\text { of these events over time, } \\
\text { and to analyze the causes } \\
\text { and symptoms of these } \\
\text { events in the general } \\
\text { population }\end{array}$ & $\begin{array}{l}\text { Prospective cohort, } \\
\text { non-probabilistic sample of } \\
338 \text { patients who needed } \\
\text { emergency care due to } \\
\text { hypoglycemia }\end{array}$ & $\begin{array}{l}\text { Physical activity, } \\
\text { insulin therapy and } \\
\text { stress }\end{array}$ & $\begin{array}{l}\text { Physical activity }\left(\eta 2^{* *}=\right. \\
0.030) \\
\text { Insulin }\left(\eta 2^{* *}=0.014\right) \\
\text { Stress }\left(\eta 2^{* *}=0.014\right)\end{array}$ & $2 b$ \\
\hline $\begin{array}{l}\text { Cardiovascular } \\
\text { Autonomic Dysfunction } \\
\text { Predicts Severe } \\
\text { Hypoglycemia in Patients } \\
\text { With Type } 2 \text { Diabetes: } \\
\text { A 10-Year Follow-up } \\
\text { Study }{ }^{(23)} \\
\text { Korea }\end{array}$ & $\begin{array}{l}\text { To investigate the } \\
\text { development of severe } \\
\text { hypoglycemia in the } \\
\text { presence of autonomic } \\
\text { cardiovascular neuropathy } \\
\text { in patients with type } 2 \mathrm{DM}^{+}\end{array}$ & $\begin{array}{l}\text { Prospective cohort, } \\
\text { probability sample of } 894 \\
\text { patients with type } 2 \mathrm{DM}^{\dagger}\end{array}$ & $\begin{array}{l}\text { Cardiovascular } \\
\text { autonomic } \\
\text { dysfunction }\end{array}$ & $\begin{array}{l}\mathrm{HR}^{\|}=2.43 ; \mathrm{Cl} 95 \% \pi: \\
1.21-4.84\end{array}$ & $2 b$ \\
\hline $\begin{array}{l}\text { Angiotensin- } \\
\text { Converting Enzyme } \\
\text { Insertion/Deletion } \\
\text { Polymorphism and } \\
\text { Severe Hypoglycemia } \\
\text { Complicating Type } 2 \\
\text { Diabetes: The Fremantle } \\
\text { Diabetes Study (24) } \\
\text { United States }\end{array}$ & $\begin{array}{l}\text { To determine } \\
\text { whether angiotensin- } \\
\text { converting enzyme I/ } \\
\mathrm{D} \text { gene polymorphisms } \\
\text { independently predict } \\
\text { severe hypoglycemia } \\
\text { in community-acquired } \\
\text { patients with type } 2 \mathrm{DM}^{\dagger}\end{array}$ & $\begin{array}{l}\text { Prospective cohort, } \\
\text { non-probabilistic sample of } \\
602 \text { patients with type } 2 \mathrm{DM}^{+}\end{array}$ & $\begin{array}{l}\text { Angiotensin- } \\
\text { Converting Enzyme } \\
\text { DD Genotype }\end{array}$ & $\begin{array}{l}\mathrm{RR}^{\S}=1.80, \mathrm{Cl} 95 \% \pi: \\
1.00-3.24\end{array}$ & $2 b$ \\
\hline $\begin{array}{l}\text { Antidiabetic } \\
\text { pharmacotherapy and } \\
\text { anamnestic hypoglycemia } \\
\text { in a large cohort of type } \\
2 \text { diabetic patients - an } \\
\text { analysis of the DiaRegis } \\
\text { registry }{ }^{(25)} \\
\text { Germany }\end{array}$ & $\begin{array}{l}\text { To identify predictors of } \\
\text { hypoglycemia in patients } \\
\text { with type } 2 \mathrm{DM}^{+} \text {in the } \\
\text { use of mono or double } \\
\text { combination of oral } \\
\text { antidiabetics. }\end{array}$ & $\begin{array}{l}\text { Prospective cohort, } \\
\text { non-probabilistic sample } \\
\text { of patients with type } 2 \mathrm{DM}^{\dagger} \\
\text { aged } \geq 40 \text { years on the use } \\
\text { of antidiabetic agents alone } \\
\text { or in combination }\end{array}$ & $\begin{array}{l}\text { Age }<65 \text { years } \\
\text { reduces the incidence } \\
\text { of hypoglycemia, } \\
\text { low } \mathrm{HbA} 1 \mathrm{c}^{*} \text { and } \\
\text { heart failure, stroke } \\
\text { / transient ischemic } \\
\text { attack, use of } \\
\text { sulfonylureas }\end{array}$ & 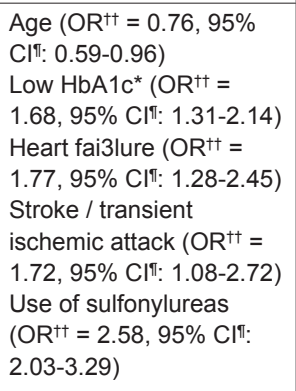 & $2 b$ \\
\hline $\begin{array}{l}\text { Metoclopramide as a risk } \\
\text { factor for postprandial } \\
\text { hyperglycemia in type } 2 \\
\text { diabetes }^{(26)} \\
\text { Mexico }\end{array}$ & $\begin{array}{l}\text { To determine whether } \\
\text { metoclopramide is a risk } \\
\text { factor for postprandial } \\
\text { hyperglycemia }\end{array}$ & $\begin{array}{l}\text { Prospective cohort, } \\
\text { non-probabilistic sample of } \\
160 \text { hospitalized patients } \\
\text { with type } 2 \mathrm{DM}^{\dagger} .\end{array}$ & $\begin{array}{l}\text { Body mass index> } \\
31 \mathrm{~g} / \mathrm{m} 2 \text {, and } \\
\text { use of intravenous } \\
\text { metoclopramide }\end{array}$ & $\begin{array}{l}\text { Body mass index }(\mathrm{RR}= \\
\left.1.4,95 \% \mathrm{Cl}^{\pi}=1.07-1.84\right) \\
\text { Metoclopramide }(\mathrm{RR}= \\
3.7,95 \% \mathrm{Cl}: 1.24-11.2)\end{array}$ & $2 b$ \\
\hline $\begin{array}{l}\text { Severe hypoglycemia } \\
\text { is associated with oral } \\
\text { antidiabetic treatment } \\
\text { compared with insulin } \\
\text { analogs in nursing home } \\
\text { patients with type } 2 \\
\text { diabetes and dementia: } \\
\text { Results from the DIMORA } \\
\text { study(27) } \\
\text { Italy }\end{array}$ & $\begin{array}{l}\text { To identify the prevalence } \\
\text { of severe hypoglycemic } \\
\text { events in a large sample } \\
\text { of elderly patients } \\
\text { with diabetes, with } \\
\text { and without dementia, } \\
\text { and to investigate the } \\
\text { association between } \\
\text { severe hypoglycemia } \\
\text { and specific antidiabetic } \\
\text { treatments (classes of } \\
\text { oral agents and types of } \\
\text { insulin analogues) }\end{array}$ & $\begin{array}{l}\text { Prospective cohort, } \\
\text { population of } 2258 \text { residents } \\
\text { of } 150 \text { long-term institutions } \\
\text { with type } 2 \mathrm{DM}^{\dagger} \text { between } \\
65-110 \text { years }\end{array}$ & $\begin{array}{l}\text { Dementia, } \\
\text { monotherapy with } \\
\text { sulfonylureas, or } \\
\text { combination of } \\
\text { metformin and } \\
\text { sulfonylureas }\end{array}$ & $\begin{array}{l}\text { Dementia }\left(\mathrm{OR}^{+\dagger}=2.029\right. \\
\left.95 \% \mathrm{Cl}^{\top} 1.325-3.108\right) \\
\text { Sulphonylureas }\left(\mathrm{OR}^{+\dagger}=\right. \\
8.805,95 \% \mathrm{Cl}^{\Uparrow}=4,260- \\
18,201) \\
\text { Combination of metformin } \\
\text { and sulfonylureas }\left(\mathrm{OR}^{+\dagger}\right. \\
=6.639 ; 95 \% \mathrm{Cl}^{3} 3,273- \\
14,710\end{array}$ & $2 b$ \\
\hline
\end{tabular}




\begin{tabular}{|c|c|c|c|c|c|}
\hline $\begin{array}{l}\text { Title of the article and } \\
\text { country of publication }\end{array}$ & Objective & Design and casuistry & $\begin{array}{l}\text { Risk Factor } \\
\text { identified }\end{array}$ & $\begin{array}{l}\text { Measures of effect } \\
\text { and } \mathrm{Cl} 95 \% \pi \text { (when } \\
\text { available) }\end{array}$ & $\begin{array}{l}\text { Level of } \\
\text { evidence }\end{array}$ \\
\hline $\begin{array}{l}\text { Identifying factors } \\
\text { associated with } \\
\text { hypoglycemia-related } \\
\text { hospitalizations among } \\
\text { elderly patients with type } \\
2 \text { DM in the US: a novel } \\
\text { approach using influential } \\
\text { variable analysis( }{ }^{(2)} \\
\text { United States }\end{array}$ & $\begin{array}{l}\text { To understand the } \\
\text { factors associated with } \\
\text { hospitalizations for } \\
\text { hypoglycemia among } \\
\text { adults with type } 2 \mathrm{DM}^{\dagger} \text {, } \\
\text { with emphasis on the } \\
\text { elderly }\end{array}$ & $\begin{array}{l}\text { Retrospective cohort, } \\
\text { probability sample of } \\
887,182 \text { patients with type } \\
2 \mathrm{DM}^{+} \text {using documentation } \\
\text { from hospitalization }\end{array}$ & $\begin{array}{l}\text { Age (>65 vs } \\
<65 \text { years), use } \\
\text { of sulfonylurea } \\
\text { and / or insulin, } \\
\text { previous history of } \\
\text { hospitalization due to } \\
\text { hypoglycemia, kidney } \\
\text { disease }\end{array}$ & 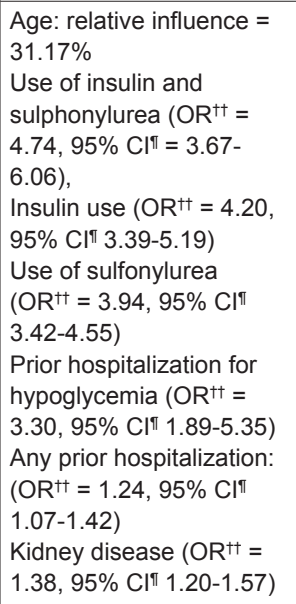 & $3 b$ \\
\hline $\begin{array}{l}\text { Impact of clinical factors } \\
\text { and CYP2C9 variants } \\
\text { for the risk of severe } \\
\text { sulfonylurea-induced } \\
\text { hypoglycemia } \\
\text { Germany }\end{array}$ & $\begin{array}{l}\text { To compare the } \\
\text { distribution of different } \\
\text { variant CYP2C9 alleles } \\
\text { in a large cohort of } \\
\text { patients with type } 2 \mathrm{DM}^{\dagger} \\
\text { who presented severe } \\
\text { hypoglycemia against } \\
\text { a control group without } \\
\text { severe hypoglycemia }\end{array}$ & $\begin{array}{l}\text { Case-control, } \\
\text { population-based sample } \\
\text { of } 102 \text { consecutive } \\
\text { patients with type } 2 \mathrm{DM}^{\dagger} \\
\text { and severe hypoglycemia } \\
\text { in use and sulfonylurea } \\
\text { (cases), and } 101 \text { patients } \\
\text { with type } 2 \mathrm{DM}^{\dagger} \text { treated } \\
\text { with sulfonylurea without } \\
\text { a history of severe } \\
\text { hypoglycemia (controls) } \\
\text { matched by sex, age, } \\
\text { body mass index, and co- } \\
\text { medication }\end{array}$ & $\begin{array}{l}\text { Low levels of HbA1c*, } \\
\text { presence of coronary } \\
\text { disease; CYP2C9 } \\
\text { genotypes and } \\
\text { co-medication with } \\
\text { other drugs, with at } \\
\text { least one CYP2C9 } \\
\text { substrate }\end{array}$ & $\begin{array}{l}\mathrm{HbA} 1 \mathrm{C}^{*}(\mathrm{RR}=1.56,95 \% \\
\mathrm{Cl}=1.20-2.04) \\
\text { Coronary disease (RR } \\
=2.38,95 \% \mathrm{Cl}^{\pi}=1.35- \\
4.18) \\
\text { Genotypes CYP2C9 } \\
\text { (RR }=0.58,95 \% \mathrm{Cl}= \\
0.14-2.50) \\
\text { Co-medication }(\mathrm{RR}= \\
0.34,95 \% \mathrm{Cl} \text { : } 1.20-2.04)\end{array}$ & $3 b$ \\
\hline $\begin{array}{l}\text { Predictors of } \\
\text { hypoglycemia insulin- } \\
\text { treated type } 2 \text { diabetes } \\
\text { patients in primary care: } \\
\text { A retrospective data base } \\
\text { analysis } \\
\text { (30) } \\
\text { Germany }\end{array}$ & $\begin{array}{l}\text { To investigate the } \\
\text { frequency and predictors } \\
\text { of hypoglycemia in type } 2 \\
\mathrm{DM}^{+} \text {patients treated with } \\
\text { insulin }\end{array}$ & $\begin{array}{l}\text { Retrospective cohort, } \\
\text { a probabilistic sample of } \\
32,545 \text { patients with type } \\
2 \mathrm{DM}^{+} \text {and / or regular oral } \\
\text { antidiabetic prescriptions } \\
\text { were eligible for the analysis }\end{array}$ & \begin{tabular}{|l|} 
Kidney failure \\
autonomic \\
neuropathy, \\
adrenocortical \\
insufficiency, \\
depression, dementia \\
and affective \\
disorders
\end{tabular} & $\begin{array}{l}\text { Kidney failure }\left(\mathrm{OR}^{+\dagger}=\right. \\
1.26,95 \% \mathrm{Cl} 1.16-1.37) \\
\text { Autonomic neuropathy } \\
\left(\mathrm{OR}^{+\dagger}=1.34,95 \% \mathrm{Cl}\right. \\
1.20-1.49) \\
\text { Adrenocortical } \\
\text { insufficiency }\left(\mathrm{OR}^{\dagger}=3.08 \text {, }\right. \\
\left.95 \% \mathrm{Cl}^{\pi}=1.35-7.05\right) \\
\text { Depression }\left(\mathrm{OR}^{+\dagger}=1.24,\right. \\
\left.95 \% \mathrm{Cl}^{\pi} 1.13-1.35\right) \\
\text { Dementia }\left(\mathrm{OR}^{+\dagger}=1.49\right. \\
\left.95 \% \mathrm{Cl}^{\pi}=1.31-1.35\right) \\
\text { Affective disorders }\left(\mathrm{OR}^{+\dagger}\right. \\
=1.80,95 \% \mathrm{Cl}=1.36- \\
2.38)\end{array}$ & $3 b$ \\
\hline $\begin{array}{l}\mathrm{HbA} 1 \mathrm{c} \text { and risk of severe } \\
\text { hypoglycemia in type } 2 \\
\text { diabetes } \\
\text { United States }\end{array}$ & $\begin{array}{l}\text { To examine the } \\
\text { association between } \\
\text { the level of } \mathrm{HbA} 1 \mathrm{c}^{\star} \text { and } \\
\text { severe self-reported } \\
\text { hypoglycemia in patients } \\
\text { with type } 2 \mathrm{DM}^{+}\end{array}$ & $\begin{array}{l}\text { Retrospective cohort, } \\
\text { probability sample of } 9,094 \\
\text { patients with type } 2 \mathrm{DM}^{\dagger}, \\
\text { aged } 30-77 \text { years, and } \\
\text { treated with hypoglycemic } \\
\text { therapy }\end{array}$ & \begin{tabular}{|l|} 
Almost normal \\
glycemic control \\
$\left(\mathrm{Hb} 1 \mathrm{Ac} c^{*}<6 \%\right)$ and \\
very poor glycemic \\
control $\left(\mathrm{Hb} \mathrm{Ac}^{*} \geq 9 \%\right)$
\end{tabular} & $\begin{array}{l}\text { Almost normal glycemic } \\
\text { control }(\mathrm{RR}=1.25,95 \% \\
\left.\mathrm{Cl}^{\pi}=0.99-1.57\right) \\
\text { Very poor glycemic } \\
\text { control }\left(\mathrm{RR}^{\S}=1.16,95 \%\right. \\
\mathrm{Cl}=0.97-1.38)\end{array}$ & $3 b$ \\
\hline $\begin{array}{l}\text { Impact of race on } \\
\text { the incidence of } \\
\text { hypoglycemia in } \\
\text { hospitalized older adults } \\
\text { with type } 2 \text { diabetes } \\
\text { England }\end{array}$ & $\begin{array}{l}\text { To determine the impact of } \\
\text { skin color on the incidence } \\
\text { of hypoglycemia during } \\
\text { the hospitalization of the } \\
\text { elderly with type } 2 \mathrm{DM}^{+}\end{array}$ & $\begin{array}{l}\text { Retrospective cohort, } \\
\text { non-probabilistic sample } \\
\text { of electronic records of } \\
650 \text { hospitalized patients } \\
>65 \text { years, with confirmed } \\
\text { diagnosis of type } 2 \mathrm{DM}^{\dagger}, \\
\text { who presented one or more } \\
\text { episodes of hypoglycemia }\end{array}$ & $\begin{array}{l}\text { Males, age }>75 \text { years, } \\
\text { black skin color, use } \\
\text { of home or hospital } \\
\text { insulin, blood glucose } \\
\text { level at hospital } \\
\text { admission }\end{array}$ & 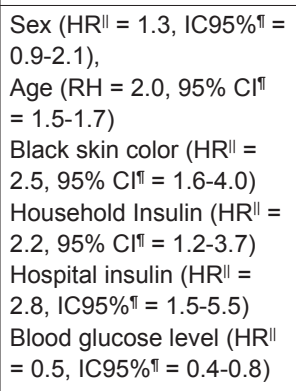 & $3 b$ \\
\hline
\end{tabular}

(the Figure 3 continue in the next page...) 


\begin{tabular}{|c|c|c|c|c|c|}
\hline $\begin{array}{l}\text { Title of the article and } \\
\text { country of publication }\end{array}$ & Objective & Design and casuistry & $\begin{array}{l}\text { Risk Factor } \\
\text { identified }\end{array}$ & $\begin{array}{c}\text { Measures of effect } \\
\text { and } \mathrm{CI} 95 \%{ }^{\pi} \text { (when } \\
\text { available) }\end{array}$ & $\begin{array}{l}\text { Level of } \\
\text { evidence }\end{array}$ \\
\hline $\begin{array}{l}\text { Tight glycemic control } \\
\text { and use of hypoglycemic } \\
\text { medications in older } \\
\text { veterans with type } 2 \\
\text { diabetes and comorbid } \\
\text { dementia }{ }^{(33)} \\
\text { United States }\end{array}$ & $\begin{array}{l}\text { To identify risk factors } \\
\text { for rigid glycemic control } \\
\text { in elderly people with } \\
\text { dementia receiving } \\
\text { antidiabetic therapy, and } \\
\text { to identify the prevalence } \\
\text { and characteristics of } \\
\text { patients at high risk of } \\
\text { hypoglycemia }\end{array}$ & $\begin{array}{l}\text { Retrospective cohort, } \\
\text { probabilistic sample of } \\
15,880 \text { elderly }>65 \text { years } \\
\text { with type } 2 \mathrm{DM}^{\dagger} \text {, dementia } \\
\text { and using antidiabetic } \\
\text { medicine }\end{array}$ & $\begin{array}{l}\text { Age }>75 \text { years, } \\
\text { weight loss, chronic } \\
\text { lung disease, chronic } \\
\text { anemia }\end{array}$ & $\begin{array}{l}\text { Age }\left(\mathrm{OR}^{+\dagger} 75-84 \text { years }\right. \\
=1.16,95 \% \mathrm{Cl}^{\pi}=1.07- \\
1.26, \mathrm{OR}^{+\dagger} \geq 85 \text { years } \\
=1.13, \mathrm{OR}^{+\dagger} 95 \%= \\
1.02-1.25) \\
\text { Weight loss }\left(\mathrm{OR}^{+\dagger}=1.36 \text {, }\right. \\
\left.95 \% \mathrm{Cl}^{\pi}=1.09-1.69\right) \\
\mathrm{Chronic}^{+} \text {lung disease } \\
\left(\mathrm{OR}^{\dagger}=1.10,95 \% \mathrm{Cl}^{\top}=\right. \\
1.01-1.21) \\
\text { Chronic anemia }\left(\mathrm{OR}^{+\dagger}\right. \\
=1.12,95 \% \mathrm{Cl}=1.02- \\
1.22)\end{array}$ & $3 b$ \\
\hline $\begin{array}{l}\text { Fasting glucose level is } \\
\text { associated with nocturnal } \\
\text { hypoglycemia in elderly } \\
\text { male patients with type } 2 \\
\text { diabetes }^{(34)} \\
\text { China }\end{array}$ & $\begin{array}{l}\text { To investigate whether } \\
\text { fasting glycemia is an } \\
\text { indicator of nocturnal } \\
\text { hypoglycemia in elderly } \\
\text { men with type } 2 \mathrm{DM}^{+}\end{array}$ & $\begin{array}{l}\text { Transversal, } \\
\text { non-probabilistic sample of } \\
291 \text { elderly diabetic men }\end{array}$ & $\begin{array}{l}\text { Fasting glycemia }<6.1 \\
\mathrm{mmol} / \mathrm{L}\end{array}$ & 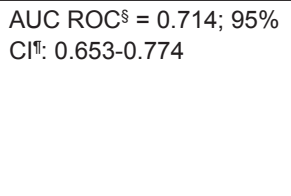 & 4 \\
\hline $\begin{array}{l}\text { Risk factors for } \\
\text { hypoglycemia-related } \\
\text { hospitalization in patients } \\
\text { with type } 2 \text { diabetes: } \\
\text { a nested case-control } \\
\text { study }^{(35)} \\
\text { United States }\end{array}$ & $\begin{array}{l}\text { Identify risk factors for } \\
\text { hospitalization due to } \\
\text { hypoglycemia in patients } \\
\text { with type } 2 \mathrm{DM}^{\dagger} \text { treated } \\
\text { with oral hypoglycemic } \\
\text { agents }\end{array}$ & $\begin{array}{l}\text { Nested case-control, } \\
\text { probability sample of } \\
1339 \text { patients with type } \\
2 \mathrm{DM}^{\dagger} \text { treated with } \\
\text { hypoglycemic, hospitalized } \\
\text { for hypoglycemia, and } \\
13,390 \text { patients with } \\
\text { type } 2 \mathrm{DM}^{+} \text {treated } \\
\text { with hypoglycemic } \\
\text { not hospitalized for } \\
\text { hypoglycemia, matched } \\
\text { for sex, age and area of } \\
\text { residence }\end{array}$ & $\begin{array}{l}\text { Prior emergency or } \\
\text { outpatient care due } \\
\text { to hypoglycemia; } \\
\text { Continuous and } \\
\text { intermittent availability } \\
\text { of sulfonylurea }\end{array}$ & $\begin{array}{l}\text { Emergency care }\left(\mathrm{OR}^{\dagger \dagger}\right. \\
=9.48,95 \% \mathrm{Cl}^{\pi}: 4.95- \\
18.15) \\
\text { Outpatient care (OR } \\
=7.88,95 \% \mathrm{Cl}^{\dagger \dagger}: 5.68- \\
10.93) \\
\text { Continuous availability } \\
\text { of sulfonylurea (OR } \\
\left.2.25,95 \% \mathrm{Cl}^{\pi \dagger}: 1.93-2.63\right) \\
\text { Intermittent availability } \\
\text { of sulfonylurea }\left(\mathrm{OR}^{\dagger \dagger}=\right. \\
\left.1.22,95 \% \mathrm{Cl}^{\pi}: 1.01-1.47\right)\end{array}$ & 4 \\
\hline $\begin{array}{l}\text { ABCC8 polymorphism } \\
\text { (Ser1369Ala): influence } \\
\text { on severe hypoglycemia } \\
\text { due to sulfonylureas }{ }^{(36)} \\
\text { Japan }\end{array}$ & $\begin{array}{l}\text { To analyze the value of } \\
\text { the Ser1369Ala variant as } \\
\text { a predictive risk factor for } \\
\text { hypoglycemia caused by } \\
\text { binding sulfonylureas to } \\
\text { the A + B site. }\end{array}$ & $\begin{array}{l}\text { Case-control, non- } \\
\text { probabilistic sample of } 32 \\
\text { patients with type } 2 \mathrm{DM}^{+} \\
\text {admitted to the hospital } \\
\text { with severe hypoglycemia, } \\
\text { and } 125 \text { patients with type } \\
2 \mathrm{DM}^{\dagger} \text { without severe } \\
\text { hypoglycemia, without } \\
\text { matching for demographic or } \\
\text { clinical characteristics }\end{array}$ & $\begin{array}{l}\text { Ser1369Ala variant } \\
\text { is not a predictive } \\
\text { factor of severe } \\
\text { hypoglycemia }\end{array}$ & $\begin{array}{l}\mathrm{OR}^{+\dagger}=1.65 ; 95 \% \mathrm{Cl} \text { : } \\
0.92-2.96\end{array}$ & 4 \\
\hline $\begin{array}{l}\text { Association of KCNJ11 } \\
\text { E23K gene polymorphism } \\
\text { with hypoglycemia in } \\
\text { sulfonylurea-treated type } \\
2 \text { diabetic patients }{ }^{(37)} \\
\text { Greek }\end{array}$ & $\begin{array}{l}\text { To investigate the possible } \\
\text { association of KCNJ11 } \\
\text { E23K polymorphism } \\
\text { with incidence of mild } \\
\text { hypoglycemic events } \\
\text { induced by sulfonylureas }\end{array}$ & $\begin{array}{l}\text { Transversal, non- } \\
\text { probabilistic sample of } 176 \\
\text { patients with type } 2 \mathrm{DM}^{+} \\
\text {who received sulfonylurea } \\
\text { were included in the } \\
\text { study. } 92 \text { patients who } \\
\text { had experienced drug- } \\
\text { associated hypoglycemia } \\
\text { and } 84 \text { who never } \\
\text { experienced hypoglycemia } \\
\text { during treatment with } \\
\text { sulfonylurea }\end{array}$ & $\begin{array}{l}\text { Polymorphism } \\
\text { KCNJ11 E23K is } \\
\text { not associated with } \\
\text { an increased risk of } \\
\text { hypoglycemia }\end{array}$ & Data not shown & 4 \\
\hline $\begin{array}{l}\text { Association between } \\
\text { excessive daytime } \\
\text { sleepiness and severe } \\
\text { hypoglycemia in people } \\
\text { with type } 2 \text { diabetes } \\
\text { United Kingdom }\end{array}$ & $\begin{array}{l}\text { To investigate whether } \\
\text { sleep disturbance and } \\
\text { increased daytime } \\
\text { sleepiness are associated } \\
\text { with a higher frequency of } \\
\text { severe hypoglycemia in } \\
\text { people with type } 2 \mathrm{DM}^{+}\end{array}$ & $\begin{array}{l}\text { Transversal, population- } \\
\text { based sample of } 898 \\
\text { patients with type } 2 \mathrm{DM}^{\dagger} \\
\text { Edinburgh study participants }\end{array}$ & $\begin{array}{l}\text { Sleepiness Scale } \\
\text { (Epworth Sleepiness } \\
\text { Scale) }\end{array}$ & $\mathrm{OR}^{+\dagger}=0,537$ & 4 \\
\hline
\end{tabular}

*HbA1c: Glycated Hemoglobin; †DM2: Type 2 diabetes mellitus; $¥$ P: Percentile; §AUC ROC: area under the ROC curve; IIHR Risk Ratio; १IC: Confidence interval; $* * n 2$ : Cohen correlation; +†OR: Odds Ratio; $\neq$ RR: Relative Risk

Figure 3 - Characteristics of the selected articles. São Paulo, SP, Brazil, 2015. 


\begin{tabular}{|c|c|}
\hline Risk factor described in NANDA-I & Risk factor found in the review \\
\hline \multicolumn{2}{|c|}{ Risk factors for increased blood glucose levels } \\
\hline Insufficient diabetes management & Elevated levels of $\mathrm{HbA1c}$ associated with elevated fasting hyperglycemia ${ }^{(18)}$ \\
\hline Excessive weight gain & Body Mass Index>31 Kg/m²(26) \\
\hline \multicolumn{2}{|c|}{ Risk factors for decreased blood glucose levels } \\
\hline \multirow{2}{*}{ Insufficient diabetes management } & Previous history of hypoglycemia ${ }^{(28,35)}$ \\
\hline & Low levels of $\mathrm{HbA} 1 \mathrm{c}^{(29-31)}$ \\
\hline $\begin{array}{l}\text { Alteration in mental status } \\
\text { Delay in cognitive development }\end{array}$ & Cognitive deficit/Dementia ${ }^{(20,27)}$ \\
\hline \multirow[b]{2}{*}{ Compromised physical health status } & Cardiovascular autonomic neuropathy ${ }^{(23)}$ \\
\hline & $\begin{array}{l}\text { Comorbidities: cardiovascular, pulmonary, kidney, liver, cerebrovascular, } \\
\text { psychiatric diseases, adrenocortical failure }(25,28,33,38)\end{array}$ \\
\hline Excessive weight loss & Weight loss ${ }^{(33)}$ \\
\hline
\end{tabular}

Figure 4 - Correspondences between NANDA-I risk factors for risk for unstable blood glucose level in people with type 2 diabetes mellitus, and those identified in a literature review. São Paulo, 2015.

Risk factors for increased blood glucose levels

Intravenous metoclopramide ${ }^{(26)}$

Risk factors for decreased blood glucose levels

Advanced age ${ }^{(28,31,33)}$; African-American race $^{(32)}$; Longer duration of Diabetes mellitus diagnosis ${ }^{(24,30)}$; Daytime sleepiness $^{(38)}$; Macroalbuminuria ${ }^{21)}$; Genetic polymorphisms: CYP2C9 ${ }^{(19,29)}$ and angiotensin converting enzyme ${ }^{(24)}$; In people treated with insulin: total daily doses of insulin; association of insulins $^{(22,28)}$; In people treated with oral antidiabetics: use of sulfonylureas; combination of metformin and sulfonylureas ${ }^{(25,27-28,35)}$; Inadequate physical activity ${ }^{(20)} ;$ Fasting blood glucose level $<6.1 \mathrm{mmol} / \mathrm{L}^{(34)}$

Figure 5 - Risk factors for risk for unstable blood glucose level in people with type 2 diabetes mellitus identified in a literature review, without correspondence to NANDA-I risk factors. São Paulo, 2015.

\section{Discussion}

This review identified the risk factors for unstable blood glucose levels in people with type 2 DM. Most articles studied the reduction of blood glucose levels, especially severe hypoglycemia.

Hypoglycemia is the most common acute variation in diabetic patients, especially in type 1 and type 2 diabetes, and type 2 insulin-treated diabetes. It is defined as blood glucose levels lower than $70 \mathrm{mg} / \mathrm{dL}$. Severe hypoglycemia, i.e., hypoglycemia requiring administration of carbohydrates, glucagon, or other resuscitative actions, is a potentially fatal condition ${ }^{(39)}$.

It was possible to establish a correspondence of the risk factors identified in the review with six NANDA-I risk factors: insufficient diabetes management; excessive weight gain, compromised physical health status; alteration in mental status; delay in cognitive development; and excessive weight loss. Although it was not possible to establish a correspondence with the other NANDA-I risk factors, the authors of this review do not think they should be disregarded. Clinical experience shows that these risk factors can contribute to variations in blood glucose levels in people with type 2 DM.

One exception is the risk factor, Rapid growth period. Type 2 DM is more common after 40 years old, whereas type 1 DM affects mainly children and adolescents( ${ }^{(39)}$. Thus, this risk factor seems more suitable for people with type $1 \mathrm{DM}$.
A correspondence was found between the NANDA-I risk factor, insufficient diabetes management, with high or low $\mathrm{HbA} 1 \mathrm{c}$ and a previous history of hypoglycemia. The management of a chronic disease, such as type 2 DM, extrapolates the biological aspects ${ }^{(40)}$, however the biological markers are still considered the gold standard for its investigation. In the context of type 2 DM, HbA1c is a method that allows for the assessment of glycemic control in the long term ${ }^{(39)}$. Therefore, the assessment of $\mathrm{HbA1c}$ by nurses is not only valuable for the assessment of the history of the person with type 2 DM, but also for the risk assessment of future glycemic variation.

Compromised physical health status is a NANDA-I risk factor that can be understood, in this context, as the presence of chronic diseases, such as: coronary heart disease, cardiovascular autonomic neuropathy, heart failure, chronic anemia, kidney damage, depression, mood disorders and adrenocortical insufficiency, which may compromise the physical health of people with type $2 \mathrm{DM}^{(25,28,33,38)}$. In addition to the number of multiple comorbidities, their type and severity can be important influences on prioritizing care for individuals with diabetes, and on the ability of self-care performance for people with DM and, consequently, glycemic variation ${ }^{(41)}$.

Another factor that can undermine self-care ability, increase the number of medication errors of people with DM, represent associated comorbidity or frailty, and thereby increase the risk of hypoglycemia is daytime 
sleepiness $^{(38)}$. However, sleepiness may have different causes, one of which can be hypoglycemia itself.

The NANDA-I risk factors, "alteration in mental status" and "delay in cognitive development", are related to impaired cognitive status and dementia, identified in this review. They can affect the functional ability and self-care of patients with type 2 DM (20), an essential requirement to prevent episodes of glycemic variation and the emergence of acute and chronic complications related to the disease ${ }^{(42)}$.

Weight loss, found in this review can have a correspondence with the NANDA-I risk factor, "excessive weight loss". Weight loss is common in type 2 DM, probably due to the catabolism that characterizes the disease. Additionally, certain drugs used to treat the disease can cause weight loss(43). In fact, weight loss may be considered a risk factor for glucose variations, especially hypoglycemia, when the given dosage is not adjusted to weight changes.

Another factor associated with a higher likelihood of increasing blood glucose levels was the intravenous use of metoclopramide, which antagonizes the effects of incretins. This interaction induces glucose-dependent insulin secretion and inhibits glucagon secretion, leading to postprandial hyperglycemia(26,44).

Regarding risk factors that increase the likelihood of lowering blood glucose levels, the following were also identified: age; African-American ethnicity; longer duration of diabetes; insulin therapy; therapy with oral antidiabetic agents; macroalbuminuria; inadequate physical activity; and genetic factors.

Advanced age is associated with an increased risk of hypoglycemia, due to factors such as: adverse effects of medication, poor nutrition, cognitive impairment, renal failure, autonomic dysfunction, and long-term $\mathrm{DM}^{(45)}$. Also regarding age, several studies selected in this review emphasize caution in the use of sulfonylureas in the elderly, because they have greater chances of developing severe hypoglycemia(25,27).

Regarding race, one study showed that the hypoglycemic risk in African-Americans was 2.5 to 3 times that of Caucasians, especially in the first days of hospitalization. The authors of the study explain the finding by the likely lack of adherence to treatment at home and the diminished capacity of the HbA1c test to accurately assess glycemic control in AfricanAmericans, environmental factors and lifestyle ${ }^{(32)}$. As only one study found a relationship between race and risk of hypoglycemia, this result should be interpreted with caution.

The complexity of treatment regimens with insulin, associated with the need for greater attention to glycemic control, may explain the higher incidence of hypoglycemic events in patients under this type of treatment ${ }^{(22,33)}$. The use of simpler regimens and insulin analogs can minimize these risks ${ }^{(46)}$.

With regard to oral antidiabetics, the American Diabetes Association and the European Association for the Study of Diabetes reinforce that it is necessary to personalize glucose control, by balancing benefits and risks, taking into account the adverse effects of hypoglycemic agents, age and health status, among other factors. The side effects of these medications may lead to the risk of hypoglycemia, especially when associated with others ${ }^{(47)}$.

The recommendation to personalize glucose control is reinforced by the fact that genetic factors have also been found to be precipitants for hypoglycemic events. Carriers of the CYP2C9 variant allele may be more likely to experience mild attacks of hypoglycemia during treatment with oral antidiabetic sulfonylureas ${ }^{(19)}$. Individuals with type 2 DM with these polymorphisms may respond more frequently with hypoglycemia.

Although macroalbuminuria is a recognized marker of glomerular injury, the underlying mechanisms that could explain their relationship with hypoglycemia are not yet fully understood ${ }^{(21)}$. However, when individuals with type 2 DM have diabetic nephropathy with macroalbuminuria, nursing attention towards the possibility of hypoglycemia should be increased.

Inadequate exercise was found to be a risk factor for severe hypoglycemia. The causes include: reducing food intake; longer intervals between meals and exercise; unexpected increase of exercise intensity or duration; increased insulin absorption (depending on location and time of application); summed effect of hypoglycemic agent or insulin with exercise. There are also other situations in which the risk of hypoglycemia increases, such as alcohol abuse or gastrointestinal disorders, such as diarrhea and vomiting. Since physical activity is an important aspect in the treatment of DM because it promotes a better sensitivity of tissues to insulin, there should be attention to adjustment of antidiabetic medications, greater glycemic control, and an analysis of the need for carbohydrate intake to perform physical activities without hypoglycemic episodes(37).

This review is limited by the restriction of the search regarding year of publication, idiom and primary studies, and the non-inclusion of gray literature (publication bias), which may have contributed to a failure to identify other risk factors. Additionally, the heterogeneity of the articles was verified empirically by the authors, based on the different methodological characteristics, and did not allow for data integration or conducting a meta-analysis. 


\section{Conclusion}

This review updated the existing knowledge on risk factors for the diagnosis, risk for unstable blood glucose level. Nineteen risk factors for risk for unstable blood glucose level in patients with type 2 DM were identified. Of those, 11 were not included in the NANDA-I diagnostic classification. It is believed that the ND concept analysis associated with the extension of the present review, as well as the development of conceptual and operational definitions, may contribute to the studies of this phenomenon.

The identified risk factors can help nurses in clinical practice to plan and implement care strategies to improve the health outcomes of individuals with type 2 DM at risk of hypo- or hyper-glycemia. Nurse educators can use up-to-date content regarding risk factors for teaching undergraduate students regarding care for individuals with type 2 DM.

\section{References}

1. Herdman $\mathbf{T H}$, Kamitsuru S. NANDA International nursing diagnoses: definitions \& classification, 20152017. Oxford: Willey-Blackwell; 2014.

2. Speksnijder $H$, Mank $A$, Achterberg $T$. Nursing Diagnoses (NANDA-I) in hematology-oncology: a delphistudy. Int J Nurs Terminol Classif. 2011;22(2):77-91. doi: 10.1111/j.1744-618X.2011.01183.x.

3. Araújo D, Carvalho R, Chianca T. Nursing diagnoses identified in records of hospitalized elderly. Invest Educ Enferm. 2014;32(2):225-35. doi: 10.1590/S012053072014000200005 .

4. Moura P, Braga L, Domingos C, Rodrigues N, Correia M, Oliveira L. Diagnoses and nursing interventions in hypertensive and diabetic individuals according to Orem's Theory. Rev Rene. 2014;15(6):1039-46. doi: 10.15253/2175-6783.2014000600018

5. Silva L, Carmona E, Beck A, Lima M, Araújo E. Nursing diagnoses in diabetic patients medical charts: a descriptive study. Online Braz J Nurs [Internet]. 2013 [citado 24 maio 2016];12(1):62-72. Disponível em: http://www.objnursing.uff.br/index.php/nursing/ article/view/3894/pdf

6. Benamer S, Eljazwi I, Mohamed R, Masoud H, Tuwati M, Elbarsha AM. Association of hyperglycemia with inhospital mortality and morbidity in Libyan patients with diabetes and acute coronary syndromes. Oman Med J. 2015;30(5):326-30. doi: 10.5001/omj.2015.67.

7. Ying C, Zhou X, Chang Z, Ling H, Cheng X, Li W. Blood glucose fluctuation accelerates renal injury involved to inhibit the AKT signaling pathway in diabetic rats.
Endocrine. 2016;53(1):81-96. doi: 10.1007/s12020016-0867-z. Epub 2016 Feb 9

8. Torimoto K, Okada Y, Mori H, Tanaka Y. Relationship between fluctuations in glucose levels measured by continuous glucose monitoring and vascular endothelial dysfunction intype 2 diabetes mellitus. Cardiovasc Diabetol. 2013;12:1. doi:10.1186/1475-2840-12-1.

9. Ministério da Saúde (BR). Secretaria da Atenção à Saúde. Cadernos de Atenção Básica - Estratégias para o cuidado de pessoas com doença crônica - Diabetes Mellitus. [Internet]. Brasília; 2013. [citado 12 jan 2016]. Disponível em:http://bvsms.saude.gov.br/bvs/ publicacoes/estrategias_cuidado_pessoa_diabetes_ mellitus_cab36.pdf.

10. Brandão SMG, Altino DM, Silva RCG, Lopes JL. Defining characteristics of decreased cardiac output: a literature review. Int J Nurs Terminol Classif. 2011 Apr-Jun;22(2):92-102. doi: 10.1111/j.1744618X.2010.01174.x.

11. Silva RCG, Brunorio L, Giribela CRG, Bortolotto

LA, Wolosker N, Consolim-Colombo FM. Distances walked in the six-minute walk test: suggestion of defining characteristic for the nursing diagnosis Ineffective Peripheral Tissue Perfusion. Rev. Latino-Am. Enfermagem. 2012;20(2):251-8. doi: http://dx.doi. org/10.1590/S0104-116920120002000006

12. Mendes K, Silveira R, Galvão C. Revisão integrativa: Método de pesquisa para a incorporação de evidências na saúde e na enfermagem. Texto Contexto Enferm [Internet]. 2008;17(4):758-64. doi: dx.doi. org/10.1590/S0104-07072008000400018

13. Santos C, Pimenta C, Nobre M. The PICO strategy for the research question construction and evidence search. Rev. Latino-Am. Enfermagem. [Internet] 2007 [cited June 29 2016];15(3):508-11.

14. Barbosa LB, Vasconcelos SML, Correia LOS, Ferreira RC. Estudos de avaliação do conhecimento nutricional de adultos: uma revisão sistemática. Ciência Saúde Coletiva. 2016;21(2):449-62. doi: 10.1590/141381232015212.20182014

15. Silva DFO, Lyra CO, Lima SCVC. Padrões alimentares de adolescentes e associação com fatores de risco cardiovascular: uma revisão sistemática. Ciência Saúde Coletiva. 2016;21(4):1181-95. doi: 10.1590/141381232015214.08742015

16. Centre For Evidence Based Medicine [Internet]. Oxford Centre for Evidence-based Medicine - Levels of Evidence (March 2009) [cited Feb 4 2017]. Available from: http://www.cebm.net/oxford-centre-evidencebased-medicine-levels-evidence-march-2009/

17. Morimoto A, Nishimura R, Tsujino D, Taki K, Tajima N, Utsunomiya K. Relationship among A1C, hypoglycemia, and hyperglycemia in Japanese with 
type2 diabetes - resultsfromcontinuous glucose monitoring data. Diabetes Technol Therapeut. 2011;13(6),667-70. doi: 10.1089/dia.2010.0230. Epub 2011 Apr 2.

18. Schernthaner G, Guerci B, Gallwitz B, Rose L, Nicolay C, Kraus P. Impact of postprandial and fasting glucose concentrations on $\mathrm{HbA1c}$ in patients with type 2 diabetes. Diabetes Metabol. 2010;36(5):389-94. doi: 10.1016/j.diabet.2010.04.004. Epub 2010 Jul 2.

19. Gökalp O, Gunes A, Çam H, Cure E, Aydın O, Tamer $M$, et al. Mild hypoglycaemic attacks induced by sulphonylureas related to CYP2C9, CYP2C19 and CYP2C8 polymorphisms in routine clinical setting. Eur J ClinPharmacol. 2011; 67(12):1223-9. doi: 10.1007/ s00228-011-1078-4. Epub 2011 Jun 21.

20. Punthakee Z, Miller M, Launer L, Williamson J, Lazar $R$, Cukierman-Yaffee $T$, et al. Poor cognitive function and risk of severe hypoglycemia in type 2 diabetes: post hoc epidemiologic analysis of the ACCORD trial. Diabetes Care. 2012;35(4):787-93. doi: 10.2337/dc11-1855. Epub 2012 Feb 28.

21. Yun J, Ko S, Ko S, Song K, Ahn Y, Yoon K, et al. Presence of macroalbuminuria predicts severe hypoglycemia in patients with type 2 diabetes: a 10year follow-up study. Diabetes Care. 2012;36(5):12839. doi: 10.2337/dc12-1408. Epub 2012 Dec 17.

22. Krnacova V, Kubena A, Macek K, Bezdek M, Smahelova A, Vlcek J. Severe hypoglycaemia requiring the assistance of emergency medical services frequency, causes and symptoms. Biomed Pap Med Fac Univ Palacky Olomouc Czech Repub. 2012;156(3):2717. doi: 10.5507/bp.2012.037. Epub 2012 May 25.

23. Yun J, Kim J, Song K, Ahn Y, Yoon K, Yoo K, et al. Cardiovascular autonomic dysfunction predicts severe hypoglycemia in patients with type 2 diabetes: a 10 year follow-up study. Diabetes Care. 2013;37(1):23541. doi: $10.2337 /$ dc13-1164

24. Davis W, Brown S, Jacobs I, Bulsara M,Beilby J, Bruce $D$, et al. Angiotensin-Converting enzyme insertion/ deletion polymorphism and severe hypoglycemia complicating type 2 diabetes: The Fremantle Diabetes Study. J ClinEndocrinolMetab. 2011;96(4):E696-700. doi: 10.1210/jc.2010-2087. Epub 2011 Feb 2.

25. Tschöpe D, Bramlage P, Binz C, Krekler M, Plate T, Deeg E, Gitt A. Antidiabetic pharmacotherapy and anamnestic hypoglycemia in a large cohort of type 2 diabetic patients - an analysis of the DiaRegis registry. CardiovascDiabetol. 2011;10-66.

doi: 10.1186/1475-2840-10-66

26. Gutiérrez-Hermosillo $H$, León-González $E$, Santiago D, Cedillo-Rodríguez J, Gutiérrez Hermosillo V, Taméz-Pérez H. Metoclopramida, factor de riesgo para hiperglucemia postprandial en diabetes tipo 2 .
Nutricion Hospital. 2012; 27(4):1267-71. http://dx.doi. org/10.3305/nh.2012.27.4.5607

27. Abbatecola A, Bo M, Barbagallo M, Incalzi R, Pilotto A, Bellelli $G$, et al. Severe hypoglycemia is associated with antidiabetic oral treatment compared with insulin analogs in nursing home patients with type 2 diabetes and dementia: results from the DIMORA Study. J Am Med Dir Assoc. 2015; 16(4): 349.e7-12. doi: 10.1016/j. jamda.2014.12.014. Epub 2015 Feb 7.

28. Fu H, Xie W, Curtis B, Schuster D. Identifying factors associated with hypoglycemia-related hospitalizations among elderly patients with T2DM in the US: a novel approach using influential variable analysis. Curr Med Res Opin. 2014;30(9):1787-93. doi: 10.1185/03007995.2014.922944. Epub 2014 May 29.

29. Holstein A, Hahn M, Patzer O, Seeringer A, Kovacs $P$, Stingl J. Impact of clinical factors and CYP2C9 variants for the risk of severe sulfonylurea-induced hypoglycemia. Eur J Clin Pharm. 2011; 67(5):471-6. doi: 10.1007/ s00228-010-0976-1. Epub 2011 Jan 7.

30. Kostev K, Dippel F, Rathmann W. Predictors of hypoglycaemia in insulin-treated type 2 diabetes patients in primary care: a retrospective database analysis. Prim Care Diabetes. 2014;8(2):127-31. doi: http://dx.doi. org/10.1016/j.pcd.2013.10.001

31. Lipska K, Warton E, Huang E, Moffet H, Inzucchi S, Krumholz $\mathrm{H}$, et al. HbA1c and risk of severe hypoglycemia in type 2 diabetes: The Diabetes and Aging Study. Diabetes Care. 2013;36(11): 3535-42. doi: 10.2337/ dc13-0610. Epub 2013 Jul 30.

32. Ghazi A, Landerman L, Lien L, Colon-Emeric C. Impact of race on the incidence of hypoglycemia in hospitalized older adults with type 2 diabetes. Clin Diabetes. 2013;31(2):66-72.

33. Thorpe C, Gellad W, Good C, Zhang S, Zhao X, Mor M, Fine $M$. Tight glycemic control and use of hypoglycemic medications in older veterans with type 2 diabetes and comorbid dementia. Diabetes Care. 2015;38(4): 58895. doi: 10.2337/dc14-0599. Epub 2015 Jan 15.

34. Fang F, Xiao H, Li C, Tian H, Li J, Li Z, et al. Fasting glucose level is associated with nocturnal hypoglycemia in elderly male patients with type 2 diabetes. Aging Male. 2013;16(3):132-6. doi: 10.3109/13685538.2013.818111. Epub 2013 Jul 22.

35. Quilliam BJ, Simeone JC, Ozbay AB. Risk factors for hypoglycemia-related hospitalization in patients with type 2 diabetes: a nested case-control study. Clin Therapeut. 2011;33(11):1781-91. doi: 10.1016/j. clinthera.2011.09.020. Epub 2011 Oct 22.

36. Sato R, Watanabe H, Genma R, Takeuchi M, Maekawa M, Nakamura, H. ABCC8 polymorphism (Ser1369Ala): influence on severe hypoglycemiadue to sulfonylureas. 
Pharmacogenomics. 2010;11(12):1743-50. doi: 10.2217/pgs.10.135.

37. Ragia G, Tavridou A, Petridis I, Manolopoulos V. Association of KCNJ11 E23K gene polymorphism with hypoglycemia in sulfonylurea-treated type 2 diabetic patients. Diabetes Res Clin Pract. 2012;98(1):119-24. doi: 10.1016/j.diabres.2012.04.017. Epub 2012 May 14. 38. Inkster $B$, Riha $R$, Look $L$, Williamson $R$, Mclachlan S, Frier B, Strachan M, Price J, Reynolds R. Association between excessive daytime sleepiness and severe hypoglycemia in people with type 2 diabetes: the Edinburgh type 2 diabetes study. Diabetes Care. 2013;36(12):4157-9. doi: 10.2337/dc13-0863. Epub 2013 Oct 2.

39. Sociedade Brasileira de Diabetes. Diretrizes da Sociedade Brasileira de Diabetes. [Internet]. 2015. [citado 11 jan 2016]. Disponível em: http://www. diabetes.org.br/images/2015/area-restrita/diretrizessbd-2015.pdf.

40. Achutti A. Control of noncommunicable diseases historical context and elements for its discussion. Rev Direito Sanitário. 2015;15(2):73-90.

41. Kerr EA, Heisler M, Krein SL, Kabeto M, Langa KM, Weir D, Piette JD. Beyond Comorbidity counts: how do comorbidity type and severity influence diabetes patients' treatment priorities and self-management? J Gen Intern Med. 2007; 22(12):1635-40. doi: doi:10.1007/s11606007-0313-2.

42. Stacciarini T, Pace A. Translation, adaptation and validation of a self-care scale for type 2 diabetes patients using insulin. Acta Paul Enferm. 2014;27(3): 221-9. http://dx.doi.org/10.1590/1982-0194201400038

43. Domecq J, Prutsky G, Wang Z, Elraiyah T, Brito J, Mauck $K$, et al. Drugs commonly associated with weight change: umbrella systematic review and meta-analysis (Protocol). Syst Rev. 2012; 29;1:44. doi: 10.1186/20464053-1-44.

44. Tambascia M, Malerbi D, Eliaschewitz F. Influence of gastric emptying on the control of postprandial glycemia: physiology and therapeutic implications. Einstein. 2014;12(2): 251-253. http://dx.doi.org/10.1590/S167945082014RB2862
45. Amorim CC, Pessoa FS. Envelhecimento e saúde da pessoa idosa: principais agravos e riscos à saúde. [Internet]. Universidade Federal do Maranhão UNASUS/UFMA. 2014. [citado 17 jan 2016]. Disponível em: https://ares.unasus.gov.br/acervo/bitstream/handle/ ARES/1748/Mod10.Un3. pdf? sequence $=1$.

46. Sociedade Brasileira de Endocrinologia e Metabologia \& Associação Brasileira de Nutrologia. Diabetes Mellitus Tipo 2: insulinização. [Internet]. 2011 [citado 11 jan 2016] Disponível em: http://www.projetodiretrizes.org.br/ diretrizes10/diabetes_mellitus_tipo_2_insulinizacao.pdf.

47. Inzucchi SE, Bergensta RM, Buse JB, Diamant M, Ferrannin E, Nauck M, et al. Management of hyperglycemia in type 2 diabetes, 2015: a patient-centered approach: update to a position statement of the American Diabetes Association and the European Association for the Study of Diabetes. Diabetes Care. [Internet]. 2015 [cited May 25 2016]; 38(1):140-9. Available from: http://care. diabetesjournals.org/content/diacare/38/1/140.full.pdf
Corresponding Author:

Rita de Cassia Gengo e Silva

Universidade de São Paulo. Escola de Enfermagem

Av. Dr. Enéas de Carvalho Aguiar, 419

Bairro: Cerqueira César

CEP: 05403-000, São Paulo, SP, Brasil

E-mail: rita.gengo@usp.br
Copyright $\odot 2017$ Revista Latino-Americana de Enfermagem This is an Open Access article distributed under the terms of the Creative Commons (CC BY).

This license lets others distribute, remix, tweak, and build upon your work, even commercially, as long as they credit you for the original creation. This is the most accommodating of licenses offered. Recommended for maximum dissemination and use of licensed materials. 